\title{
A demarcação de áreas de preservação permanente ao longo dos rios
}

\author{
João de Deus Medeiros \\ Departamento de Botânica, Universidade Federal de Santa Catarina \\ Campus Universitário Trindade, Caixa Postal 476, CEP 88040-900, Florianópolis - SC, Brasil \\ j.d.medeiros@ufsc.br
}

Submetido em 12/09/2012

Aceito para publicação 12/03/2013

\section{Resumo}

Através da análise da reforma legislativa do novo Código Florestal brasileiro (Lei n. 4.771/65), este artigo mostra a evolução da proteção legal ao sistema ripário (faixas marginais), definido como os cordões de vegetação ao longo dos rios e outros corpos d'água, os quais variam de acordo com a largura do corpo d'água. A demarcação das áreas de preservação permanente ao longo dos rios é um processo complexo que tem provocado dúvidas e conflitos. Sistemas ripários são espaços voltados à expansão da agricultura e, assim, encontram-se sob pressão. A análise mostrou que o limite imposto pela nova norma está de acordo com o princípio da razoabilidade. A revisão do novo Código Florestal brasileiro, que no momento encontra-se em pauta no Congresso Nacional, poderá contribuir positivamente para que se alcance o possível e desejado equilíbrio entre respeito ao ambiente natural e expansão dos usos da terra.

Palavras-chave: Lei ambiental; Uso da terra; Zonas ripárias

\section{Abstract}

The demarcation of permanent preservation areas along rivers. Through the analysis of the new Brazilian Forest Code (Law 4,771/65) legislative reform, this paper shows the evolution of legal protection to the riparian system (marginal strips), defined as vegetation strings along rivers and other water bodies, which vary according to the water body width. The demarcation of permanent preservation areas along rivers is a complex process which has led to doubts and conflicts. Riparian systems are spaces aimed at the agricultural expansion and, thus, they're under pressure. The analysis showed that the limitation posed by the new rule agrees with the principle of reasonableness. The new Brazilian Forest Code review, which is currently included in the National Congress agenda, will be able to positively contribute to achieve the possible and desired balance between respect to the natural environment and expansion of land uses.

Key words: Environmental law; Land use; Riparian zones 


\section{Introdução}

O Brasil possui vasta rede hídrica e é detentor da maior bacia hidrográfica do planeta, a Amazônica, que cobre área de $7.008 .370 \mathrm{~km}^{2}$, dos quais $64,88 \%$ encontra-se em território nacional. Em parte decorrente desta abundância, o processo de ocupação do território vincula-se a exploração predatória dos recursos naturais, com reflexos negativos sobre a qualidade e disponibilidade dos recursos hídricos (RIBEIRO et al., 2005).

Desde o período imperial o Brasil tem produzido marcos legais para regrar o uso dos recursos hídricos, dentre os quais a lei no 4.771 , de 15 de setembro de 1965, que instituiu o "Novo Código Florestal”, definindo as chamadas áreas de preservação permanente (APP), cobertas ou não por vegetação nativa, com a função ambiental de preservar os recursos hídricos, a paisagem, a estabilidade geológica, a biodiversidade, o fluxo gênico de fauna e flora, proteger o solo e assegurar o bem estar

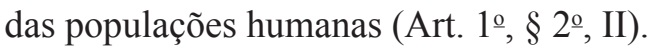

O artigo 2o da lei o 4.771 determinava como APP a faixa localizada ao longo dos rios ou de qualquer curso d'água desde o seu nível mais alto em faixa marginal cuja largura mínima variava entre $30 \mathrm{~m}$ até $500 \mathrm{~m}$. A alínea $a$ ado artigo $2^{\circ}$ trata de "rios ou curso d'água" e a extensão da faixa marginal é estipulada em metros. $\mathrm{O}$ ponto inicial dessa faixa, apesar de sua importância para a correta operação da norma, recebeu diversos tratamentos e interpretações. A mesma alínea $a$ estipulava que essa medição se inicia "desde o seu nível mais alto em faixa marginal". Durante o processo legislativo de revisão do "Novo Código Florestal" esse tema foi objeto de intensos debates. Não apenas se questiona a largura das faixas marginais, mas também as interpretações dadas ao conceito de "nível mais alto", o que resulta em divergências significativas tanto na interpretação do objeto protegido (rio ou curso d'água) e consequentemente da sua largura, bem como na extensão da faixa marginal que deveria ser protegida nos termos dos itens 1 a 5 da alínea $a$.

Com a recente edição da lei no 12.651 , de 25 de maio de 2012, essa condição foi alterada, passando a figurar agora como referencia a borda da calha do leito regular, por força do artigo $4^{\circ}$. A referida lei ainda define no seu artigo 3 , inciso XIX, leito regular como "a calha por onde correm regularmente as águas do curso d'água durante o ano".

A alteração promovida no critério para medição da APP é significativa, e suas implicações na operação da norma nacional, assim como na efetividade da proteção pretendida precisam ser adequadamente avaliadas. $\mathrm{O}$ tratamento dado aos terrenos marginais de cursos d'água na legislação nacional é motivo recorrente de controvérsias, e sua aplicação ocorreu de modo precário, avolumando-se criticas e conflitos, muitos desses externados no processo de revisão legislativa do Código Florestal. O presente trabalho procura analisar essas implicações e consequências das distintas interpretações conferidas a expressão "nível mais alto", constante da alínea $a$ do artigo $2^{\circ}$ da lei $\mathrm{n}^{-} 4.771 / 65$, e da recente alteração desta referencia com a edição da lei no $12.651 / 2012$, na perspectiva de contribuir para a correta implementação da proteção conferida pela norma geral nacional, a qual se associa a definição de faixas marginais, cobertas ou não por vegetação, com largura variável em função da largura do curso d'água.

\section{Material e Métodos}

O estudo consiste na avaliação dos documentos apresentados durante a tramitação, na Câmara dos Deputados, do Projeto de Lei no 1.876 , de 1999 (CÂMARA, 1999), e no Senado, onde recebeu a designação de PLC 30, de 2011 (SENADO, 2011), transformado em norma jurídica com veto parcial em 28 de maio de 2012, passando a constituir a lei $\mathrm{n}^{\mathrm{o}} 12.651$ de 2012.

Complementando a avaliação do processo legislativo, que inclui a análise da documentação apresentada durante as audiências públicas promovidas nas comissões por onde tramitou a matéria, promoveuse uma revisão da legislação correlata, e da literatura concernente a zonas ripárias. 


\section{Resultados}

\section{Revisão da legislação correlata}

Desde a edição da lei oํ 1.507 , de 26 de setembro de 1867 , se estabelece restrições ao uso das terras nas margens dos rios. A referida lei, em seu artigo 39 estabelecia: "Art. 39. Fica reservada para a servidão publica nas margens dos rios navegáveis e de que se fazem os navegáveis, fora do alcance das marés, salvas as concessões legitimas feitas até a data da publicação da presente lei, a zona de sete braças contadas do ponto médio das enchentes ordinárias para o interior, e o Governo autorizado para concedê-la em lotes razoáveis na forma das disposições sobre os terrenos de marinha". Uma braça equivale a $2,2 \mathrm{~m}, \log$ o o afastamento do ponto médio das enchentes, mencionado no art. 39 da lei no $1.507 / 1867$, seria de $15,4 \mathrm{~m}$ para o interior.

Posteriormente, o Decreto no 23.793, de 23 de janeiro de 1934, que aprova o Código Florestal, definiu como florestas protetoras as que, por sua localização, servirem conjunta ou separadamente para: a) conservar o regime das águas; e, b) evitar a erosão das terras pela ação dos agentes naturais (Art. $4^{\circ}$ ). Adicionalmente "proíbe, mesmo aos proprietários, derrubar, nas regiões de vegetação escassa, para transformar em lenha, ou carvão, matas ainda existentes ás margens dos cursos d'água, lagos e estradas de qualquer natureza entregues á serventia publica" (Art. 22). Por outro lado, prevê que "os proprietários de terras, próximas de rios e lagos, navegados por embarcações a vapor, ou de estradas de ferro que pretenderem explorar a indústria da lenha para abastecimento dos vapores e maquinas, não poderão iniciar o corte de madeiras sem licença da autoridade florestal" (art. 25). Nenhuma menção é feita a extensão dessas florestas protetoras.

Em 10 de julho de 1934 foi editado o Decreto nº 24.643, denominado Código de Águas, considerando que o uso das águas no Brasil regia-se até aquele momento por uma legislação obsoleta, em desacordo com as necessidades e interesse da coletividade nacional, e que se tornava necessário modificar aquele estado de coisas, dotando o país de uma legislação adequada que, de acordo com a tendência da época, permitisse ao poder público controlar e incentivar o aproveitamento industrial das águas.

O Código de Águas ao estabelecer, em seu Art. 14, que "os terrenos reservados são os que, banhados pelas correntes navegáveis, fora do alcance das marés, vão até a distância de $15 \mathrm{~m}$ para a parte de terra, contados desde o ponto médio das enchentes ordinárias", e com a complementação pelo artigo 15, definindo que "o limite que separa o domínio marítimo do domínio fluvial, para o efeito de medirem-se ou demarcarem-se 33 (trinta e três), ou $15 \mathrm{~m}$, conforme os terrenos estiverem dentro ou fora do alcance das marés, será indicado pela seção transversal do rio, cujo nível não oscile com a maré ou, praticamente, por qualquer fato geológico ou biológico que ateste a ação poderosa do mar", na pratica manteve as determinações do artigo 39 da lei no 1.507/1867.

Complementando a norma da época, o Decreto-lei no 9.760/46 conceituou em seu Art. 4o como terrenos marginais aqueles que banhados pelas correntes navegáveis, fora do alcance das marés, vão até a distância de $15 \mathrm{~m}$, medidos horizontalmente para a parte da terra, contados desde a linha média das enchentes ordinárias. O referido Decreto define como da competência do então Serviço do Patrimônio da União (SPU) a determinação da posição das linhas do preamar médio do ano de 1831 e da média das enchentes ordinárias (Art. 9º), e que a referida determinação será feita "à vista de documentos e plantas de autenticidade irrecusável, relativos àquele ano, ou, quando não obtidos, a época que do mesmo se aproxime" (Art. 10).

Passados 55 anos da edição do Decreto-lei no 9.760/46, a Instrução Normativa SPU no $²$, de 12 de março de 2001 estabelece procedimentos para a demarcação dos terrenos de marinha e dos terrenos marginais. Segundo a IN 2 terrenos marginais são identificados e caracterizados, nas correntes de água fora do alcance das marés, a partir da Linha Média das Enchentes Ordinárias - LMEO (Lei no 1.507/1867), nos termos do Decreto-lei no 9.760, de 1946, determinada pela interseção do plano representativo do nível médio das enchentes ordinárias com o terreno, considerando-se, caso tenha ocorrido qualquer alteração, sua configuração em 1867 (Art. 7ํ). A Linha Média das Enchentes Ordinárias, por sua vez, será determinada a partir de plantas e documentos 
de autenticidade irrecusável, relativos ao ano de 1867 ou, quando não obtidos, à época que do mesmo mais se aproxime, e de observações fluviométricas, considerando enchentes com período de recorrência igual ou superior

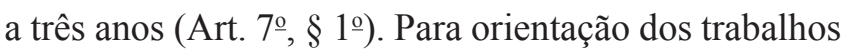
fica definido o período de recorrência como o intervalo médio de tempo entre a ocorrência de enchentes com vazões máximas iguais ou superiores à da enchente em questão (Art. 7oㅗ $\S 2^{\circ}$ ).

A referida IN 2 estabelece ainda que a Secretaria do Patrimônio da União (SPU) estabelecerá em Orientação Normativa os procedimentos que serão adotados no âmbito das Gerências Regionais de Patrimônio da União na demarcação dos terrenos de marinha e marginais (Art. 12).

Em 04 de junho de 2001 a SPU edita a Orientação Normativa que disciplina a demarcação de terrenos marginais e seus acrescidos (ON-GEADE-003). A Orientação Normativa define Caixa de um Rio ou Leito Menor como a parte do canal ocupada pelas águas e cuja frequência impede o crescimento da vegetação. Esse tipo de leito é delimitado por margens bem definidas. Também define Linha Média das Enchentes Ordinárias - LMEO, como a linha que delimita a faixa de terrenos marginais, pelo lado da margem do rio; e ainda Linha Limite dos Terrenos Marginais - LLTM como a linha traçada à distância de $15 \mathrm{~m}$, medidos horizontalmente para a parte da terra, a partir da LMEO.

Com o advento da Constituição de 1988 o domínio público dos terrenos marginais é reforçado, já que são definidos como bens da União, dentre outros, os lagos, rios e quaisquer correntes de água em terrenos de seu domínio, ou que banhem mais de um Estado, sirvam de limites com outros países, ou se estendam a território estrangeiro ou dele provenham, bem como os terrenos marginais e as praias fluviais (Art. 20, III).

Sob a égide da lei no 4.771/65, o Conselho Nacional do Meio Ambiente (CONAMA) interpretou a metodologia de verificação de APP das faixas marginais de rios ou cursos d'água, disponibilizando duas resoluções que tratam do tema, a resolução CONAMA ${ }^{\circ}$ 04/85 (revogada pela Resolução nº 303/02), que definia "leito maior sazonal" como sendo a calha alargada ou maior de um rio, ocupada nos períodos anuais de cheia; e a resolução CONAMA no $303 / 02$, que passa a definir "nível mais alto" como o nível alcançado por ocasião da cheia sazonal do curso d'água perene ou intermitente.

Seguindo a determinação da Resolução CONAMA no 303/02, para a correta aplicação do artigo 2º alínea $a$ da lei ํㅡ 4.771/65, mostrava-se necessário identificar o nível alcançado pela cheia sazonal, e tomando por referencia os limites do referido nível, define-se a largura do curso d'água e, uma vez estabelecida esta largura, projeta-se as faixas marginais que deverão ser preservadas.

Não obstante as divergências de interpretação quanto a dominialidade das faixas marginais, notadamente considerando a determinação dos terrenos marginais e as praias fluviais como bens da União, a avaliação aqui apresentada não é influenciada por esta questão, visto que a definição de APP do artigo $2^{\circ}$ da lei no ${ }^{-0}$.771/65 se dava pelo só efeito da referida lei, incidindo indistintamente sobre terras públicas e privadas, o que não se altera

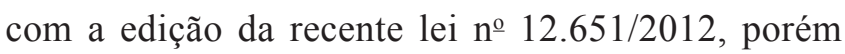
terá repercussão sobre a definição da responsabilidade pela recuperação de áreas de preservação permanente indevidamente alteradas.

\section{Sobre a definição do bem protegido}

As faixas marginais determinadas na alínea $a$ do artigo 2 o do Novo Código Florestal prestam-se a proteção dos rios ou de qualquer curso d'água. A hidrologia define rio como curso d'água de grande dimensão que serve de canal natural para a drenagem de uma bacia. Os cursos, ou as correntes de água são definidos como massa de água escoando geralmente num canal superficial natural (ANA, 2001). A partir dessas definições as águas correntes naturais classificam-se em rios, riachos e torrentes, não havendo, contudo critério quantitativo objetivo para distinguir riacho de rio, dependendo a designação muitas vezes dos usos e costumes locais.

O texto constitucional e o Código de Águas empregam o termo correntes de água, enquanto a alínea $a$ do artigo $2^{\circ}$ do Novo Código Florestal adotava o vocábulo curso d'água. Tecnicamente não há conflito entre os termos empregados, uma vez que são sinônimos e abrangem os cursos ou correntes denominados rios. 


\section{Discussão}

\section{Solbre a vegetação ao longo dos cursos d'água}

A vegetação natural associada às margens de cursos d'água recebe denominações diversas. É tratada como floresta ciliar, entendida como sinônimo de mata ciliar; como floresta ou mata de galeria; vegetação ripária, floresta ripícola ou ciliar, floresta de condensação, mata aluvial, floresta paludosa ou de várzea, floresta de brejo, formação ribeirinha, áreas das formações pioneiras com influência fluvial ou lacustre, armazenamento florestal ripariano, ou ainda faixa de armazenamento e floresta de interflúvio, aquela que cresce no terreno entre cursos d'água. Segundo Ab'Saber (2000) as matas ciliares são formações florestais que ocupam as margens de cursos d'água. Barbosa (1997) comenta que os termos usualmente empregados pelos técnicos e cientistas no Brasil são floresta ciliar e floresta de galeria.

Na classificação das regiões fitoecológicas do Brasil (IBGE, 1992) constata-se que a vegetação ocorrente nas faixas mencionadas na alínea $a$ do artigo $2^{\circ}$ da lei $n^{\circ}$ 4.771/65 é representada por distintas formações. Ela pode ser tipificada como floresta ombrófila densa aluvial, formação ribeirinha ou "floresta ciliar" que corre ao longo dos cursos d'água ocupando terraços antigos das planícies quaternárias; floresta ombrófila mista aluvial, formação ribeirinha, que ocupa sempre os terrenos aluvionares situados nos flúvios das serras costeiras ou dos planaltos; floresta estacional semidecidual aluvial; floresta estacional decidual aluvial; campinarana gramíneo-lenhosa; savana-estépica; ou ainda estepe gramíneo-lenhosa.

Não obstante essa distinção na classificação da vegetação brasileira, a proteção conferida pelo Novo Código Florestal aplica-se indistintamente a área coberta ou não por vegetação nativa. Assim sendo, as distintas interpretações e denominações relativas à vegetação que cobre as faixas marginais dos cursos d'água não interferem na aplicação da norma, e tampouco auxiliam para a correta identificação do ponto correspondente ao nível mais alto do curso d'água. A utilização dos diferentes vocábulos, curso d'água, correntes, rios, por sua vez, não gera obstáculo à correta implementação da norma.

Kobiyama (2003) apresenta revisão sobre o termo relacionado ao espaço próximo a corpos d'água em bacias hidrográficas, concluindo que o termo zona ripária é mais adequado para chamar esse espaço, que o autor define como um espaço tridimensional contendo vegetação, solo e rio. Sua extensão horizontal é definida pelo alcance da inundação, e verticalmente do regolito (abaixo) até o topo da copa da floresta (acima). A determinação desta extensão horizontal e vertical é semelhante à de Gregory et al. (1991). Planície de inundação é geralmente superfície plana, inundada em média uma vez por 1 a 3 anos (HUPP; OSTERKAMP, 1996).

Kobiyama (2003) argumenta que ripária significa próximo ao corpo de água, tratando conceito de distância e também água, concluindo que o termo ripário é mais correto do que ciliar. A expressão "vegetação ripária" seria mais adequada se aplicada a qualquer vegetação da margem, já que a definição do termo ripário permite a abrangência não apenas da vegetação relacionada ao corpo d'água, mas também daquela localizada nas suas margens. Este termo não abrangeria somente os corpos d'água naturais, mas também aqueles criados pelo homem, como as represas e os canais (MANTOVANI, 1989; ELMORE,1992 apud SOUZA, 1999).

Segundo Gregory et al. (1991) e Hupp e Osterkamp (1996), a vegetação ripária ocupa uma das áreas mais dinâmicas da paisagem. A distribuição e composição das comunidades de plantas ripárias refletem a história da inundação. Inundações frequentes dificultam o estabelecimento da vegetação pela erosão superficial e também pelos efeitos fisiológicos da inundação. Magnitude, frequência e duração de inundação diminuem lateralmente para fora do curso ativo da água, influenciando a distribuição de espécies. Então na área próxima ao rio, a vegetação é mais nova e baixa. Mesmo na área de inundação, se distante do curso d'água, normalmente a vegetação é mais antiga e alta. Sedell et al. (1990) argumentam que variações das características hidrológicas condicionam o desenvolvimento de espécies animais e vegetais na zona ripária. Além de magnitude, frequência e duração de 
inundação, sedimentos depositados também influenciam a distribuição de espécies (MELICK; ASHTON, 1991).

Diversos fatores atuam na determinação da capacidade de erosão e transporte dos rios, sendo a velocidade a mais importante. O transporte fluvial ocorre à medida que os rios desgastam o relevo em sua parte mais elevada e levam o material particulado para sua porção mais baixa. O comportamento desse material particulado é influenciado pelo tamanho dos grãos, os quais serão depositados em distintos pontos do rio. Partículas muito finas, como a das argilas, permanecerão em suspensão até decantar em regiões de baixa velocidade da água. A vegetação ripária exerce influência significativa sobre geomorfologia fluvial por afetar resistência ao fluxo, resistência mecânica do solo em barranco, armazenamento de sedimento, estabilidade de leito e morfologia do canal (HICKIN, 1984). A floresta ripária produz escombros lenhosos que influenciam processos fluviais (KELLER; SWANSON, 1979; NAKAMURA; SWANSON, 1993). Segundo Brooks e Brierley (1997), há extensa comprovação sobre a influencia da vegetação na zona ripária modificando a eficiência geomorfológica dos eventos de inundação, refletindo a estreita relação da vegetação ripária com o ambiente fluvial. Essa relação foi revisada por Malanson (1993) que enfatizou a ecologia da paisagem.

Segundo Vannote et al. (1980), a influência da floresta ripária é maior na parte montante da bacia, onde os cursos d'água são caracterizados por pequena largura, velocidade, vazão e profundidade. Ela relativamente diminui para jusante. Kobiyama et al. (1998) mencionam que a influência biológica na hidrologia é mais acentuada quanto menor o tamanho da bacia.

As funções da zona ripária são descritas em Mander et al. (1997), Reid e Hilton (1998) e em CRJC (2001). Considerando estes trabalhos, é possível elencar como funções mais relevantes: 1) Estabilização de taludes e encostas, 2) Manutenção da morfologia do rio e proteção a inundações, 3) Retenção de sedimentos e nutrientes, 4) Mitigação da temperatura da água e do solo, 5) Fornecimento de alimento e habitat para organismos aquáticos, 6) Manutenção de corredores ecológicos, 7) Paisagem e recreação, 8) Fixação do gás carbônico, 9) Interceptação de escombros rochosos.
Silva (2003) assinala que muitos estudos foram realizados a fim de analisar a eficiência ou dimensionar a largura de faixas vegetativas, e estes demonstram que a estimativa de faixa marginal depende da função que ela deverá exercer. A aplicabilidade de uma ou mais funções dessa vegetação depende do tipo de solo, topografia, uso do solo à montante, tipo de vegetação envolvida e morfologia do rio, entre outros. Não obstante, essa projeção de faixas marginais, nos distintos estudos, considera como rio ou curso d'água o espaço do curso ativo da água, figurando dentre as funções relevantes da vegetação presente na zona ripária a manutenção da morfologia do rio e proteção a inundações. Assim, ao tratarmos uma legislação que estabelece regra para aplicação nacional, definindo faixas marginais mínimas para a proteção de rio ou curso d'água, a largura dessas faixas precisa contemplar um conjunto de funções, ainda que, isoladamente, cada uma das referidas funções seja apenas parcialmente contemplada. Aqui cabe destacar a correta orientação constitucional que remete aos Estados a responsabilidade pela complementação da norma nacional, exercendo sua competência suplementar para atender especificidades que não podem ser adequadamente contempladas numa norma geral.

O Secretariado da Convenção sobre Diversidade Biológica-CDB, ao avaliar o panorama da biodiversidade global (MMA, 2010) enfatiza que os ecossistemas de águas interiores foram alterados drasticamente nas últimas décadas. Zonas úmidas de todo o mundo têm sido e continuam a ser perdidas em ritmo acelerado. A poluição proveniente de fontes difusas ou não pontuais, particularmente agricultura, continua a ser um problema significativo e crescente em muitas partes do mundo. O Panorama da Biodiversidade Global registra o reconhecimento crescente de que a restauração ou conservação das funções naturais dos sistemas de água doce pode ser uma alternativa mais rentável do que construir estrutura física para a defesa contra enchentes ou instalações caras para tratamento de água.

Vieira e Becker (2010) destacam que o estado das pesquisas atuais oferece forte sustentação para critérios e parâmetros definidos pelo Código Florestal de 1965 e, em alguns casos, haveria necessidade de expansão das APPs, e não sua redução, ressaltando a necessidade de 
garantir que a revisão legislativa seja feita com sabedoria e cautela para que a nova lei seja efetivamente cumprida e respeitada por todos. Como a largura das faixas marginais foi mantida na nova lei 12.651 , a adoção de um critério objetivo e de aplicação direta para medição dessas faixas auxilia na implementação da norma.

\section{Da aplicação da norma geral nacional}

A lei oㅡ 4.771 de 15 de setembro de 1965, na sua primeira versão se referia tão somente a "faixa marginal" para designar a proteção conferida aos rios ou curso d'água. Considerando que a lei no 1.507/1867 e o Decreto 24.643/34 mencionavam o ponto médio das enchentes ordinárias como referencia para a medição da faixa marginal ao longo dos rios, não há porque mencionar lacuna no texto original do Código Florestal de 1965. Para a correta operação das determinações do artigo $2^{\circ}$, alínea $a$ as faixas marginais seriam posicionadas a partir do ponto médio das enchentes ordinárias. O Decreto-lei no 9.760/46 reforça essa orientação, incumbindo a SPU a responsabilidade pela determinação da linha média das enchentes ordinárias. Absolutamente razoável supor que, decorridos 19 anos, considerando a edição do Novo Código Florestal em 1965, essa determinação legal remetida a SPU já estivesse cumprida, não necessitando o legislador mencionar algo além de "faixa marginal". O fato é que ainda hoje, passados 66 anos, a determinação remetida a SPU não foi plenamente cumprida. Essa indefinição comprometeu a operação correta do artigo 2º alínea $a$ do Código Florestal.

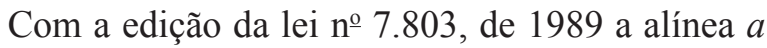
do artigo $2^{\circ}$ da lei $n^{\circ}$ 4.771/65 teve sua redação alterada, passando a figurar a expressão "desde o seu nível mais alto em faixa marginal". Com essa redação o texto legal desvincula a referencia da medição da faixa marginal ao ponto ou linha média das enchentes ordinárias. A explicação plausível para tal mudança, inviabilizando o uso da referencia a linha média das enchentes ordinárias, reside na inoperância da SPU. Assim, a partir de 1989 a correta operação da norma legal passa a depender do posicionamento correto do nível mais alto do rio ou curso d'água.

Moraes (2009) interpreta que o nível mais alto é dado por duas legislações: os mencionados Decreto no
24.643/34 (Código das Águas) e Decreto-lei no 9.760/46. Ainda segundo o autor, a linha média das enchentes ordinárias está localizada no ponto de maior abrangência do espelho d'água durante a estação chuvosa (enchente ordinária), aproveitando a marcação média de três ou mais anos. Essa interpretação contraria a orientação do referido decreto, pois esse fala em média das enchentes e não no ponto de maior abrangência.

Com a definição de "nível mais alto" estabelecido pela resolução CONAMA 302/2002, vinculando-o ao nível alcançado por ocasião da cheia sazonal do curso d'água perene ou intermitente, a correta operação da norma tornou-se mais complexa, senão impraticável. A expressão "cheia sazonal" remete a flutuação no nível da água no período anual, e essa flutuação varia em anos sucessivos, logo a faixa delimitada num dado ano vai ser distinta daquela demarcada em outros, gerando insegurança jurídica. Lindner e Silveira (2003) interpretam que o referido nível mais alto da resolução CONAMA 302/2002 equivale ao leito maior hidrológico. Os autores, através de uma representação gráfica, ilustram o leito maior hidrológico, associando-o com a largura do talude, diferenciando-se do leito maior topográfico. Ocorre que a cheia sazonal de um rio pode ultrapassar o leito maior hidrológico, acumulando-se a água ao longo do leito maior topográfico. Assim sendo, com a definição da resolução CONAMA 302/2002, a própria largura do rio fica dissociada da calha ou talude $\mathrm{e}$, consequentemente a própria largura do rio passa a variar de um ano para outro, o que gera outro problema, já que a extensão das faixas marginais varia em função da largura do rio. Silva (2003) define a largura de faixa vegetativa de zona ripária como a distância horizontal perpendicular ao rio, iniciada no fim da calha maior deste, interpretando que, segundo o Código Florestal Brasileiro, esta calha é delimitada pela maior cheia sazonal. Mesmo com a inclusão do adjetivo "maior", a interpretação de Silva (2003) também recebe a critica aqui apresentada, visto que "maior cheia" remete ao evento extremo num dado ano, evento este que, não raro, extrapola os limites da calha. Não obstante, ao remeter a medição da zona ripária ao "fim da calha maior", Silva (2003) traz uma interpretação que melhor se coaduna ao texto da lei no 12.651 de 2012 e não com a definição da Resolução CONAMA 302/2002. 
Avaliando estudos sobre APP ripária, observa-se que esse aparente conflito não é destacado, e a determinação da resolução CONAMA 302/2002 desprezada. Sparoveck et al. (2011), por exemplo, estimam que as áreas de preservação permanente ao longo das margens dos rios correspondam a 100 Mha, dos quais 43 Mha estariam em situação de não conformidade com o Código Florestal. As projeções geoespaciais apresentadas são feitas a partir de bases que consideram a rede hidrográfica nacional, com a largura definida pela calha ou curso ativo da água, não a partir do limite da cheia sazonal. Sparoveck et al. (2010) esclarecem que ao processar as informações geoespaciais para estimar as áreas de APP riparia extraem as informações de divisões geomorfológicas.

O documento intitulado "Contribuições da Academia Brasileira de Ciências (ABC) e da Sociedade Brasileira para o Progresso da Ciência (SBPC) para o Debate sobre o Código Florestal" (SBPC, 2011), aparentemente também adota avaliação similar, já que menciona que as APPs ripárias representam 6,9\% das áreas privadas, proporção que seria bastante ampliada caso adotado como referencia o ponto atingido pela cheia sazonal. Salamene et al (2011) estudando a área do leito do rio Guandu apresentam uma estratificação deste em quatro ambientes, definindo-os como leito encaixado; várzea fluvial; planície aluvionar e fluviomarinho, este ultimo referente a região próxima à foz, sem contudo explicitar a referencia adotada para estimar a extensão desses distintos ambientes. Scartazzini et al (2008) abordam diretamente esse conflito na demarcação da APP ripária, sugerindo que a alínea $a$ do artigo $2^{\circ}$ do Código Florestal fosse desmembrada, figurando uma alínea para rios situados em encostas de serras e outra para rios situados em planícies de inundação.

\section{Da revisão legislativa}

Em 06 de julho de 2010 a Comissão Especial designada para tratar do PL 1876/99 e apensados, aprovou substitutivo que altera a redação, mudando a expressão "desde o seu nível mais alto" para "desde a borda do leito menor". O substitutivo define leito menor ou álveo como "o canal por onde correm regularmente as águas do curso d'água durante o ano" (art. $3^{\circ}$, inciso V). A alteração proposta foi objeto de muitos debates ao longo da tramitação do processo, culminando com a adoção da expressão "desde a borda da calha do leito regular", expressão que foi mantida no artigo $4^{\circ}$ da lei no 12.651/2012. A norma legal ainda define leito regular como a calha por onde correm regularmente as águas do curso d'água durante o ano; e várzea de inundação ou planície de inundação como áreas marginais a cursos d'água sujeitas a enchentes e inundações periódicas (Artigo 3). Com essa redação a lei vigente abandona o conceito de nível mais alto associado à cheia sazonal, não resgatando, contudo a referencia de linha média das enchentes ordinárias. Passa a valer a referência geomorfológica da calha do curso d'água. A remissão a cheia sazonal, conforme aqui apresentado, tornava a aplicação da norma instável, portanto insegura; já o uso da linha média das enchentes ordinárias, há muito consolidada na legislação nacional e tecnicamente defensável, sofreu criticas em função da inoperância expressa do Estado na sua definição. Nesse cenário, a justificativa da adoção da referencia a "borda da calha do leito regular" surge como uma alternativa para tornar a operação da norma geral nacional mais objetiva, factível e imediata.

Segundo Sarlet e Fensterseifer (2011), ao Estado incumbe medidas positivas no sentido de assegurar a tutela do ambiente, situando a ação estatal no âmbito da dupla face do princípio da proporcionalidade, entre a proibição de excesso de intervenção, por um lado, e a proibição de insuficiência de proteção, por outro.

É razoável entender que a redução da discricionariedade da administração pública beneficia a constitucionalização da tutela ambiental, de modo que a norma objetiva facilita a atuação correta do Poder Público, notadamente dos órgãos do Poder Executivo, responsáveis pela fisscalização, gerando a desejada eficácia. Ainda segundo Sarlet e Fensterseifer (2011) a não adoção de medidas de proteção nas esferas municipal, estadual e federal, no sentido de assegurar a eficácia e efetividade do direito fundamental em questão, resulta em prática inconstitucional, passível de controle judicial, tanto sob a via abstrata quanto difusa.

No dever de proteção no plano da intervenção legislativa, o principio da proibição do excesso e do déficit, nos termos do qual o Estado está obrigado a assegurar um nível mínimo adequado de proteção dos direitos 
fundamentais, exige-se que a norma ofereça uma proteção eficiente no seu conjunto. Insurge como questão essencial verificar se a norma satisfaz suficientemente o dever de proteção, ou se, apresenta insuficiências nesse aspecto.

Ao avaliar a correta aplicação do artigo 2o, alínea $a$, da lei no 4.771 de 1965, é necessário frisar que a norma disciplina relações que se estendem no tempo e que florescerão em condições necessariamente desconhecidas do legislador. A interpretação da norma, portanto, deve ser orientada de acordo com o fim a que ela se destina. Moraes (2000) interpreta que a destinação da alínea $a$ está ligada à manutenção de umidade dos cursos, prevenindo sua extinção, e, principalmente, a queda de barrancos e encostas, evitando o assoreamento de seu leito. Como aqui debatido, as funções ambientais da zona ripária são diversas, e no âmbito da legislação federal essas faixas precisam ser entendidas como a exigência mínima, que por sua vez deverá ser adotada em todo o território nacional. Razoável entender que tais faixas poderão se mostrar insuficientes numa dada condição particular, não obstante, tal constatação não pode ser traduzida como insuficiência da norma, já que a proporcionalidade deve ser avaliada na perspectiva da atuação conjunta com os Estados, a quem incumbe a necessária complementação da norma geral nacional. A interpretação remetida pelo conceito de nível mais alto fornecido pela Resolução CONAMA 302/2002, certamente caracterizou um excesso, comprometendo a operação correta da norma. Ao remeter a medição da faixa marginal ao nível atingido pela cheia sazonal a referida resolução elimina a atuação suplementar dos Estados e, pela instabilidade da referencia, compromete a aplicabilidade e eficácia da norma, não só por excesso, mas também é possível aventar que, num ano excessivamente seco, essa referencia remeteria a faixas de APP absolutamente insuficientes, podendo a referida faixa marginal de APP ficar circunscrita ao próprio leito do rio.

A lei oㅜ 12.651 de 2012 ao estabelecer em seu Art. $4^{\circ}$ que a Área de Preservação Permanente, em zonas rurais ou urbanas, para os efeitos da referida lei são as faixas marginais de qualquer curso d'água natural, desde a borda da calha do leito regular, corrige a distorção criada com o conceito de nível mais alto associado à cheia sazonal e resguarda a desejada proporcionalidade, conferindo uma proteção adequada no seu nível mínimo, podendo assim facilitar a correta operação da norma geral nacional. Dean (1996) relata que o principal defeito do Código Florestal de 1934 era que ele nunca havia sido cumprido. Com a edição do Novo Código Florestal de 1965 essa situação se manteve, e a reação mostrada com a edição do Decreto no 6.514 de 2008 é reflexo direto dessa resistência ao cumprimento da norma: ao estabelecer prazo para comprovação da regularidade da Reserva Legal, o referido Decreto motivou intensa resistência, canalizada para a tentativa de mudança da norma geral nacional. Nesse contex to fornecer um texto com base objetiva, que permita sua aferição de forma expedita é um passo essencial e indispensável para que se obtenha a desejada eficácia da norma nacional. Não obstante, mantida a linha média das enchentes ordinárias como referencia para demarcação dos terrenos marginais definidos pela Constituição Federal como bens da União, a nova referencia para determinação da faixa de APP da lei 꾸 12.651 fará com que em muitas situações essa faixa de APP mantenha-se integralmente nos domínios da União. Como a condição de APP não é eliminada em razão da titularidade do terreno, público ou privado, resta a incerteza quanto a possibilidade de regularizar as atividades privadas consolidadas sobre tais terrenos e mesmo quanto a responsabilização pela recuperação dessas faixas indevidamente convertidas, matéria que precisa ser igualmente aprofundada para orientar a correta execução do programa de regularização ambiental previsto no artigo 59 da lei no 12.651 .

\section{Referências}

AB'SABER, A.N. O suporte geoecológico das florestas beiradeiras (ciliares). In: RODRIGUES, R. R.; LEITÃO-FILHO, H. F. (Ed.). Matas Ciliares: conservação e recuperação. São Paulo: EDUSP/ FAPESP, 2000. p. 15-25.

ANA. Glossário de termos hidrológicos. Versão 2. Agência Nacional de Águas. 2001. Disponível em: <http://hidroweb.ana. gov.br/HidroWeb.asp?TocItem=6010>. Acesso em: 29 jun. 2012.

BARBOSA, L. M. Ecological significance of gallery forests, including biodiversity. In: INTERNATIONAL SYMPOSIUM ON ASSESSMENT AND MONITORING OF FORESTS IN TROPICAL DRY REGIONS WITH SPECIAL REFERENCE TO GALLERY FORESTS. 1997, Brasília. Proceedings. Brasília: UNB, 1997. Versão eletrônica.

BROOKS, A. P.; BRIERLEY, G. J. Geomorphic responses of lower Bega River to catchments disturbance, 1851-1926. Geomorphology, Oxford, v. 18, n. 3-4, p. 291-304, 1997. 
CÂMARA. Projeto de lei 1.876 de 1999. Câmara dos Deputados. 1999. Disponível em: <http://www.camara.gov.br/proposicoesWeb/ fichadetramitacao?idProposicao=17338>. Acesso em: 20 jun. 2012.

CRJC. Connecticut River Joint Commissions. River banks and buffers. Introduction to riparian buffers. 2001. Disponível em: $<$ http://crjc.org/riparianbuffers.htm>. Acesso em: 17 jul. 2012.

DEAN, W. A ferro e fogo: a história e a devastação da Mata Atlântica brasileira. 2 reimpressão. São Paulo: Companhia das Letras, 1996. $484 \mathrm{p}$.

GREGORY, S. V.; SWANSON, F. J.; McKEE, W. A.; CUMMINS, $\mathrm{K}$. W. An ecosystem perspective of riparian zones. Focus on links between land and water. BioScience, Washington, v. 41, p. 540$551,1991$.

HICKIN, E. J. Vegetation and river channel dynamics. Canadian Geographer, Montreal, v. 28, n. 2, p. 111-126, 1984.

HUPP, C. R.; OSTERKAMP, W. R. Riparian vegetation and fluvial geomorphic processes. Geomorphology, Oxford, v. 14, n. 4, p. 277-295, 1996.

IBGE. Manual técnico da vegetação brasileira. Manuais técnicos em geociências. Rio de Janeiro: Fundação Instituto Brasileiro de Geografia e Estatística, 1992. 92 p.

KELLER, E. A.; SWANSON, F. J. Effects of large organic material on channel form and fluvial processes. Earth Surface Processes and Landform, Leeds, v. 4, n. 4, p. 361-380, 1979.

KOBIYAMA, M. Conceitos de zona ripária e seus aspectos geobiohidrológicos. In: SEMINÁRIO DE HIDROLOGIA FLORESTAL: ZONAS RIPÁRIAS, I, 2003, Alfredo Wagner. Anais... Pós-Graduação em Engenharia Ambiental - PPGEAUFSC, Florianópolis. 2003. Versão eletrônica.

KOBIYAMA, M.; GENZ, F.; MENDIONDO, E. M. Geo-BioHidrologia. In: FÓRUM GEO-BIO-HIDROLOGIA: ESTUDO EM VERTENTE E MICROBACIAS HIDROGRÁFICAS. 1998, Curitiba. Anais... Curitiba: Curso de Pós-Graduação em Solos UFPR. 1998. Versão eletrônica.

LINDNER, E. A., SILVEIRA, N. F. Q. A legislação ambiental e as áreas ripárias. In: SEMINÁRIO DE HIDROLOGIA FLORESTAL: ZONAS RIPÁRIAS, I, 2003, Alfredo Wagner. Anais... PósGraduação em Engenharia Ambiental - PPGEA-UFSC, Florianópolis. 2003. Versão eletrônica.

MALANSON, G. P. Riparian landscape. New York: Cambridge University Press, 1993. 296 p.

MANDER, U.; KUUSEMETS, V.; LÕHMUS, K.; MAURING, T. Efficiency and dimensioning of riparian buffer zones in agricultural catchments. Ecological Engineering, Columbus, v. 8, n. 4, p. 299324, 1997.

MELICK, D. R.; ASHTON, D. H. The effects of natural disturbances on warm-temperate rainforests in southeastern Australia. Australian Journal of Botany, Collingwood, v. 39, n. 1, p. 1-30, 1991

MMA. Secretariado da Convenção sobre Diversidade Biológica: Panorama da Biodiversidade global 3. Brasília: Secretaria de Biodiversidade e Florestas, 2010. 94 p.

MORAES, L. C. S. Código florestal comentado: com as alterações da lei de crimes ambientais, Lei no 9.605/98. São Paulo: Atlas, 2000. 274 p.

MORAES, L. C. S. Código florestal comentado. São Paulo: Atlas, 2009. 593 p.
NAKAMURA, F.; SWANSON, F. J. Effects of coarse woody debris on morphology and sediment storage of a mountain stream system in western Oregon. Earth Surface Processes and Landform, Leeds, v. 18, n. 1, p. 43-61, 1993.

REID, L. M.; HILTON, S. Buffering the buffer. USDA Forest Service, Albany, v. 45. p. 71-80, 1998.

RIBEIRO, C. A. A. S.; SOARES, V. P.; OLIVEIRA, A. M. S.; GLERIANI, J. M. O desafio da delimitação de áreas de preservação permanente. Revista Árvore, Viçosa, v. 29, n. 2, p. 203-212, 2005.

SALAMENE, S.; FRANCELINO, M. R.; VALCARCEL, R.; LANI, J. L.; SÁ, M. M. F. Estratificação e caracterização ambiental da área de preservação permanente do rio Guandu/RJ. Revista Árvore, Viçosa, v. 35, n. 2, p. 221-231, 2011.

SARLET, I. W.; FENSTERSEIFER, T. Notas sobre os deveres de proteção do estado e a garantia da proibição de retrocesso em matéria (sócio)ambiental. In: LIMA, A.; LAVRATTI, P.; PRESTES, V. B. (Ed.). Reforma do código florestal: limites jurídicos. São Paulo: Instituto O Direito por um Planeta Verde, 2011. p. 227-284.

SBPC. Contribuições da Academia Brasileira de Ciência (ABC) e da Sociedade Brasileira para o Progresso da Ciência (SBPC) para o debate sobre o código florestal. 2011. Disponível em: $<$ www.sbpcnet.org.br/site/arquivos/arquivo_295.pdf>. Acesso em: 14 jul. 2012

SCARTAZZINI, L. S.; KAUTZMANN, R. M.; FISCHER, A. C. Critérios para delimitar áreas de preservação permanente em rios de planície de inundação. Revista Brasileira de Recursos Hídricos, Porto Alegre, v. 13, n. 3, p. 83-91, 2008.

SEDELL, J. R.; BISSON, P. A.; SWANSON, F. J.; GREGORY, S. $\mathrm{V}$. What we know about large trees that fall into streams and rivers. In: MASER, C.; TARRANT, R. F.; TRAPPE, J. M.; FRANKLIN, J. F. (Ed.). From the forest to the sea - a story of fallen trees. Portland: USDA Forest Service, 1990. p. 47-81.

SENADO. Projeto de lei da Câmara PLC 30 de 2011. Senado Federal. 2011. Disponível em: <http://www.senado.gov.br/ atividade/materia/Consulta.asp>. Acesso em: 20 jun. 2012.

SILVA, R. V. Estimativa de largura de faixa vegetativa para zonas ripárias: uma revisão. In: SEMINÁRIO DE HIDROLOGIA FLORESTAL: ZONAS RIPÁRIAS, I, 2003, Alfredo Wagner. Anais... Pós-Graduação em Engenharia Ambiental - PPGEAUFSC, Florianópolis, 2003. Versão eletrônica.

SOUZA, M. C. Algumas considerações sobre vegetação ripária. Cadernos da Biodiversidade, Curitiba, v. 2, n. 1, p. 4-10, 1999.

SPAROVEK, G.; BARRETO, A.; KLUG, I.; PAPP, L.; LINO, J. A revisão do código florestal brasileiro. Novos Estudos, São Paulo, n. 89 , p. 111-135, 2011.

SPAROVEK, G.; BERNDES, G.; KLUG, I.; BARRETO, A. Brazilian agriculture and environmental legislation: status and future challenges. Environmental Science \& Technology, Iowa, v. 16, n. 44, p. 6046-6053, 2010.

VANNOTE, R. L.; MINSHALL, G. W.; CUMMINS, K. W.; SEDELL, L. R.; CUSHING, C. E. The river continuum concept. Canadian Journal of Fisheries and Aquatic Sciences, Ottawa, v. 37, p. 130-137, 1980.

VIEIRA, I. C. G.; BECKER, B. K. A revisão do código florestal e o desenvolvimento do país. Ciência Hoje, Rio de Janeiro, v. 46, n. 274, p. 64-67, 2010. 